\title{
KEPUASAN NASABAH DITINJAU DARI KUALITAS LAYANAN, REPUTASI PERUSAHAAN, DAN PERSEPSI KLAIM NASABAH (Studi Pada KC AJB Bumiputera 1912 Surakarta)
}

\author{
Yolanda Cahya Utami, Sri Hartono, Eny Kustiyah \\ Fakultas Ekonomi, Universitas Islam Batik Surakarta \\ Email: yolandacahyautami@gmail.com
}

\begin{abstract}
Abstrak : Tujuan dari penelitian ini adalah untuk mengetahui adakah pengaruh yang signifikan antara variabel kualitas pelanyanan, reputasi perusahaan, dan persepsi klaim nasabah dengan kepuasan nasabah. Selain itu juga untuk mengetahui apakah terdapat pengaruh secara simultan yang signifikan dan variabel mana yang paling dominan dalam mempengaruhi kepuasan nasabah pada KC AJB Bumiputera 1912 Surakarta. Metode yang dipergunakan adalah metode yang berbasis pada deskriptif kuantitatif, dimana teknik samplingnya mempergunakan Random Sampling, yaitu metode ini merupakan teknik pengambilan sampel secara acak, tanpa memperhatikan tingkatan yang terdapat dalam populasi. Data yang digunakan adalah data primer dan data sekunder dengan teknik pengumpulan data: kuesioner, observasi, wawancara, dan studi pustaka. Teknik analisis data dalam penelitian ini menggunakan linier berganda, uji determinasi (R2), uji F, dan uji t. Hasil penelitian dapat disimpulkan bahwa : 1) Ada pengaruh kualitas pelayanan, reputasi perusahaan, dan persepsi klaim nasabah secara simultan terhadap kepuasan nasabah pada KC AJB Bumiputera 1912 Surakarta, 2) Ada pengaruh kualitas pelayanan terhadap kepuasan nasabah pada KC AJB Bumiputera 1912 Surakarta Batik di Kota Solo, 3) Ada pengaruh reputasi perusahaan terhadap kepuasan nasabah pada KC AJB Bumiputera 1912 Surakarta, 4) Ada pengaruh persepsi klaim nasabah terhadap kepuasan nasabah pada KC AJB Bumiputera 1912 Surakarta.
\end{abstract}

Kata kunci : Kualitas Pelayanan, Reputasi Perusahaan, Persepsi Klaim Nasabah, Kepuasan Nasabah

\begin{abstract}
The purpose of this study is to determine whether there is a significant influence between the variable quality of service, company reputation, and customer claims perception and customer satisfaction. In addition, it is also to find out whether there is a significant simultaneous effect and which variable is the most dominant in influencing customer satisfaction at KC AJB Bumiputera 1912 Surakarta. The method used is a method based on quantitative descriptive, where the sampling technique uses Random Sampling, which is a random sampling technique, regardless of the level contained in the population. The data used are primary data and secondary data with data collection techniques: questionnaires, observations, interviews, and literature study. Data analysis techniques in this study used multiple linear, determination test (R2), F test, and t test. The results of the study can be concluded that: 1) There is an effect of service quality, company reputation, and simultaneous perception of customer claims on customer satisfaction at KC AJB Bumiputera 1912 Surakarta, 2) There is an influence of service quality on customer satisfaction at KC AJB Bumiputera 1912 Surakarta Batik in the City of Solo, 3) There is an influence of company reputation on customer satisfaction in KC AJB Bumiputera 1912 Surakarta, 4) There is an influence of customer perception perceptions of customer satisfaction on KC AJB Bumiputera 1912 Surakarta.
\end{abstract}

Keywords: Service Quality, Company Reputation, Customer Claim Perception, and Customer Satisfaction 


\section{PENDAHULUAN}

Perusahaan jasa memiliki karakteristik yang berbeda dengan perusahaan nonjasa (Kuntjoroadi dan Safitri, 2011). Asuransi adalah salah satu perusahaan yang bergerak dibidang jasa dan merupakan Lembaga Keuangan Non-Bank. Industri asuransi jiwa berhasil membukukan pertumbuhan positif di tengah melambatnya pertumbuhan ekonomi nasional.

Kepuasaan adalah perasaan senang atau kecewa seseorang yang berasal dari perbandingan antara kesannya terhadap kinerja atau hasil suatu produk dan harapan-harapannya yang telah disetujui sebelumnya (Muttaqin, 2015).

Kualitas layanan ditentukan oleh persepsi penggunanya. Penilaian baik buruknya kualitas layanan yang diberikan oleh suatu badan usaha ditentukan oleh persepsi penggunanya, sehingga setiap badan usaha dituntut untuk dapat memberikan kualitas layanan yang sebaik-baiknya pada pelanggannya untuk membedakan dengan badan usaha yang lainnya (Payne, 2011).

Reputasi perusahaan asuransi yang baik akan mempengaruhi pola pikir nasabah untuk memilih jasa asuransi pada perusahaan tersebut. Reputasi perusahaan dapat dibangun secara terencana yaitu dengan menjunjung tinggi nilai tanggung jawab, dengan menunjukkan tanggung jawab lingkungan dan tanggung jawab sosial, kemudian komunikasi yang ditandai dengan keterbukaan, pengungkapan secara penuh dan terbuka untuk berdialog. Meningkatnya dan menurunnya keputusan menggunakan jasa asuransi jiwa tentu dapat didorong oleh persepsi yang berkembang dimasyarakat (Mayer et al., 2015). Persepsi tidak saja penting dalam tahapan pemrosesan bagi perusahaan namun juga berperan pada pasca konsumsi produk barang atau jasa yaitu ketika nasabah melakukan evaluasi atas keputusan pemilihan produk barang atau jasa peda perusahaan seperti asuransi.

AJB Bumipetera 1912 merupakan perusahaan asli pribumi, keberadaan AJB Bumiputera 1912 sebagai satu-satunya perusahaan asuransi berbentuk "usaha bersama".

Berdasarkan uraian di atas dapat dipahami secara garis besar tentang arti pentingnya memahami kepuasaan nasabah yang diberikan perusahaan kepada nasabahnya. Dari uraian tersebut peneliti memilih judul "Kepuasan Nasabah Ditinjau dari Kualitas Layanan, Reputasi Perusahaan, dan Persepsi Klaim Nasabah ( Studi Pada KC AJB Bumiputera 1912 Surakarta)“.

\section{LANDASAN TEORI}

Menurut Kotler dan Keller (2015), kepuasan merupakan perasaan senang atau kecewa yang dihasilkan dari perbandingan performance produk terhadap ekspektasi mereka.

Kualitas Layanan adalah pemenuhan kebutuhan dan keinginan nasabah serta ketepatan penyampaiannya untuk mengimbangi harapan nasabah dimasa yang akan datang.

Reputasi perusahaan adalah sikap terhadap penyedia layanan atau merek, dan didirikan dan dikembangkan dalam pikiran pelanggan melalui komunikasi dan pengalaman.

Meningkatnya dan menurunnya keputusan menggunakan jasa asuransi jiwa tentu dapat didorong oleh persepsi yang berkembang dimasyarakat (Mayer et al., 2015). 


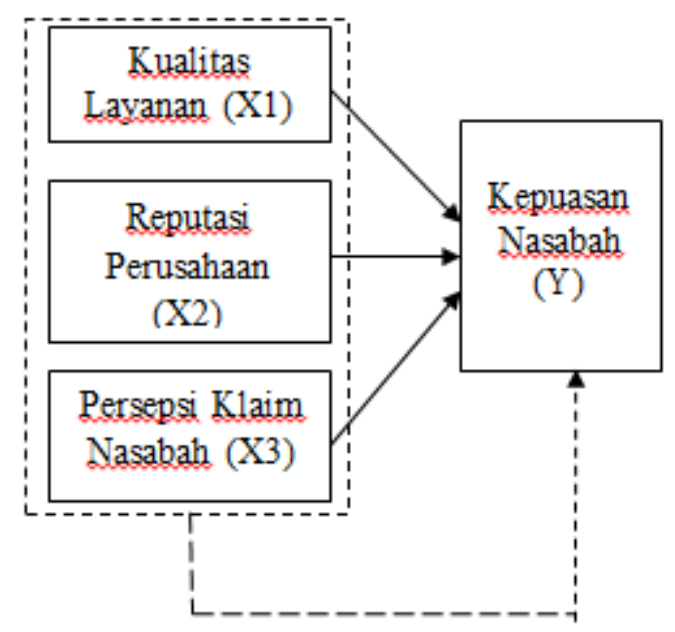

Gambar 1. Kerangka Pemikiran

\section{METODOLOGI PENELITIAN}

Penelitian ini menggunakan metode penelitian kuantitatif deskriptif. Obyek penelitian ini adalah KC AJB Bumiputera 1912 Surakarta. Populasi dalam penelitian berjumlah 960 orang. Untuk menentukan jumlah sampel digunakan rumus :

$\mathrm{n}=\frac{\mathrm{N}}{1+\mathrm{Ne}^{2}}$

Keterangan :

$\mathrm{n}=$ Jumlah sampel

$\mathrm{e}=$ Persentase tingkat kesalahan yang dapat ditoleransi

$\mathrm{N}=$ Jumlah populasi

Jadi besar sampel dapat dihitungsebagai berikut:

$$
\mathrm{n}=\frac{960}{1+960(0,1)^{2}}=99,8
$$

Dari hasil perhitungan maka dibulatkan menjadi 100 responden yang dijadikan sampel. Teknik sampling menggunakan simple ramdom sampling. Metode ini merupakan teknik pengambilan sampel secara acak, tanpa memperhatikan tingkatan yang terdapat dalam populasi tersebut (Istiatin, 2018). Pengambilan data dilakukan dengan menggunakan kuesioner. metode regresi linier berganda yang berfungsi untu menentukan apakah variabel-variabel bebas dalam penelitian ini mempunyai pengaruh signifikan terhadap kepuasan nasabah dan di dukung uji $\mathrm{F}$ dan uji t untuk mengetahui secara simultan dan parsial berpengaruh antara variabel bebas terhadap variabel bebas terhadap variabel terikat. 


\section{HASIL DAN PEMBAHASAN \\ Hasil uji Hipotesis \\ Regresi linier berganda}

Tabel. .1 Hasil Uji Regresi Linier Berganda

\begin{tabular}{|l|r|r|r|}
\hline \multicolumn{4}{|c|}{ Coefficientsa } \\
\hline Model & \multicolumn{2}{|c|}{$\begin{array}{c}\text { Unstandardized } \\
\text { Coefficients }\end{array}$} & $\begin{array}{c}\text { Standardized } \\
\text { Coefficients }\end{array}$ \\
\cline { 2 - 4 } & \multicolumn{1}{|c|}{ B } & Std. Error & \multicolumn{1}{|c|}{ Beta } \\
\hline (Constant) & 2.401 & 1.278 & .281 \\
\hline KLN & .284 & .097 & .184 \\
\hline RPS & .185 & .099 & .401 \\
\hline PKN & .386 & .095 & \\
\hline a. Dependent Variable: KPN & & \\
\end{tabular}

Sehingga diperoleh persamaan regresi sebagai berikut :

$\mathrm{Y}=2,401+0,284 \mathrm{X}_{1}+0,185 \mathrm{X}_{2}+0,386 \mathrm{X}_{3}$

a. Konstanta (a) sebesar 2,401 artinya bahwa nilai konstanta bernilai positif, hal ini menunjukkan bahwa variabel kualitas pelayanan, reputasi perusahaan, dan persepsi klaim nasabah benilai sama dengan Nol, maka nilai variabel kepuasan nasabah meningkat sebesar 2,401.

b. Koefisien regresi variabel kualitas pelayanan $\left(\mathrm{X}_{1}\right)$ mempunyai nilai positif sebesar 0,284 , artinya bahwa setiap kenaikan kualitas pelayanan $\left(\mathrm{X}_{1}\right)$ meningkat satu satuan maka kepuasan nasabah akan naik sebesar 0,284 dengan asumsi bahwa variabel bebas yang lain bernilai tetap.

c. Koefisien regresi variabel reputasi perusahaan $\left(\mathrm{X}_{2}\right)$ mempunyai nilai positif sebesar 0,185 , artinya bahwa setiap kenaikan reputasi perusahaan $\left(\mathrm{X}_{2}\right)$ meningkat satu satuan maka kepuasan nasabah akan naik sebesar 0,185 dengan asumsi bahwa variabel bebas yang lain bernilai tetap.

d. Koefisien regresi variabel persepsi klaim nasabah $\left(\mathrm{X}_{3}\right)$ mempunyai nilai positif sebesar 0,386, artinya bahwa setiap kenaikan persepsi klaim nasabah $\left(\mathrm{X}_{3}\right)$ meningkat satu satuan maka kepuasan nasabah akan naik sebesar 0,386 dengan asumsi bahwa variabel bebas yang lain bernilai tetap. 


\section{Uji F}

Perhitungan uji $\mathrm{F}_{\text {hitung }}$ sebagai berikut :

Tabel 2 hasil uji $\mathrm{F}$

\begin{tabular}{|c|c|c|}
\hline \multicolumn{3}{|l|}{ ANOVA $^{\mathrm{a}}$} \\
\hline Model & $\mathrm{F}$ & Sig. \\
\hline Regression & 47.731 & $.000^{\mathrm{b}}$ \\
\hline \multicolumn{3}{|l|}{$1 \longdiv { \text { Residual } }$} \\
\hline Total & & \\
\hline \multicolumn{3}{|c|}{ a. Dependent Variable: KPN } \\
\hline \multicolumn{3}{|c|}{$\begin{array}{l}\text { b. Predictors: (Constant), PKN, } \\
\text { KLN, RPS }\end{array}$} \\
\hline
\end{tabular}

Karena $\mathrm{F}_{\text {hitung }}>\mathrm{F}_{\text {tabel }}(47,731>2,70)$ dan nilai sig. uji $\mathrm{F}$ sebesar 0,000 lebih kecil dari 0,05 , berarti Ho ditolak, berarti kualitas pelayanan, reputasi perusahaan, dan persepsi klaim nasabah secara simultan berpengaruh signifikan terhadap kepuasan nasabah pada KC AJB Bumiputera 1912 Surakarta.

\section{Uji t}

Perhitungan uji $t_{\text {hitung }}$ sebagai berikut :

Tabel 3 Hasil Uji t

\begin{tabular}{|c|c|c|c|}
\hline \multicolumn{4}{|c|}{ Coefficients $^{\mathrm{a}}$} \\
\hline \multicolumn{2}{|c|}{ Model } & $\mathrm{t}$ & Sig. \\
\hline \multirow{4}{*}{1} & (Constant & 1.879 & .063 \\
\hline & KLN & 2.938 & .004 \\
\hline & RPS & 2.877 & .044 \\
\hline & PKN & 4.069 & .000 \\
\hline
\end{tabular}

Karena $t_{\text {hitung }}>\mathrm{t}_{\text {tabel }}(2,938>1,988)$ dan sig. sebesar 0,04 lebih kecil dari 0,05 , berarti Ho ditolak dan menerima $\mathrm{Ha}$, artinya kualitas pelayanan berpengaruh signifikan terhadap kepuasan nasabah KC AJB Bumiputera 1912 Surakarta.

Karena $t$ hitung $>\mathrm{t}_{\text {tabel }}(2,877>1,988)$ dan sig. sebesar 0,044 lebih kecil dari 0,05, berarti Ho ditolak dan menerima $\mathrm{Ha}$, artinya reputasi perusahaan berpengaruh signifikan terhadap kepuasan nasabah pada KC AJB Bumiputera 1912Surakarta.

Karena $t_{\text {hitung }}>t_{\text {tabel }}(4,069>1,988)$ dan sig. sebesar 0,000 lebih kecil dari 0,05, berarti Ho ditolak dan menerima $\mathrm{Ha}$, artinya persepsi klaim nasabah berpengaruh signifikan terhadap kepuasan nasabah pada KC AJB Bumiputera 1912 Surakarta. 


\section{Koefisien Determinasi}

Perhitungan nilai koefisien determinasi sebagai berikut :

Tabel. 4 Hasil Uji Koefisien Determinasi

\begin{tabular}{|l|l|l|l|}
\hline \multicolumn{4}{|c|}{ Model Summary } \\
\hline Model & R & R Square & $\begin{array}{l}\text { Adjusted R } \\
\text { Square }\end{array}$ \\
\hline 1 & $.775^{\mathrm{a}}$ & .601 & .589 \\
\hline
\end{tabular}

Berdasarkan hasil tabel di atas, maka dapat diketahui bahwa nilai adjusted $R$ Square $\left(\mathrm{R}^{2}\right)$ dalam penelitian ini sebesar 0,589. Sehingga dapat diartikan bahwa variasi variabel independen yang terdiri dari kualitas pelayanan $\left(\mathrm{X}_{1}\right)$, reputasi perusahaan $\left(\mathrm{X}_{2}\right)$, dan persepsi klaim nasabah $\left(\mathrm{X}_{3}\right)$ terhadap variabel dependent yaitu kepuasan nasabah pada KC AJB Bumiputera 1912 Surakarta sebesar 58,9\% sedangkan sisanya sebesar $41,1 \%$ dipengaruhi oleh faktor yang lainnya. Faktor tersebut misalnya seperti loyalitas nasabah, kepercayaan, persepsi kualitas layanan dan lain sebagainya.

\section{KESIMPULAN DAN SARAN}

\section{Kesimpulan}

Dari hasil penelitian dan analisa pada penelitian dapat ditarik kesimpulan sebagai berikut :

a. Variabel kualitas pelayanan $\left(\mathrm{X}_{1}\right)$, reputasi perusahaan $\left(\mathrm{X}_{2}\right)$ dan persepsi klaim nasabah $\left(\mathrm{X}_{3}\right)$ secara simultan berpengaruh signifikan terhadap kepuasan nasabah pada KC AJB Bumiputera 1912 Surakarta. Variabel kualitas pelayanan, reputasi perusahaan dan persepsi klaim nasabah yang baik dapat meningkatkan kepuasan nasabah pada KC AJB Bumiputera 1912 Surakarta.

b. Kualitas pelayanan secara parsial berpengaruh positif dan signifikan terhadap kepuasan nasabah pada KC AJB Bumiputera 1912 Surakarta. Artinya semakin tinggi kualitas pelayanan, maka semakin tinggi kepuasan nasabah pada KC AJB Bumiputera 1912 Surakarta.

c. Reputasi perusahaan secara parsial berpengaruh positif dan signifikan terhadap kepuasan nasabah pada KC AJB Bumiputera 1912 Surakarta. Artinya semakin tinggi reputasi perusahaan, maka semakin tinggi kepuasan nasabah pada KC AJB Bumiputera 1912 Surakarta.

d. Persepsi klaim nasabah secara parsial berpengaruh positif dan signifikan terhadap kepuasan nasabah pada KC AJB Bumiputera 1912 Surakarta. Artinya semakin tinggi persepsi klaim nasabah, maka semakin tinggi kepuasan nasabah pada KC AJB Bumiputera 1912 Surakarta.

\section{Saran}

Adapun saran penelitian ini adalah sebagai berikut:

a. Bagi perusahaan

Perusahaan asuransi Bumiputera 1912 hendaknya lebih memperhatikan tentang kualitas pelayanan, reputasi perusahaan dan persepsi klaim nasabah dalam upaya pemenuhan kepuasan nasabah.

b. Bagi penelitian selanjutnya

Bagi peneliti selanjutnya diharapkan dapat melakukan penelitian dengan cara menggunakan variabel-variabel lain yang dapat meningkatkan kepuasan nasabah dalam bidang jasa asuransi, 
sehingga dapat diketahui lebih spesifik mengenai pengaruh kualitas pelayanan, reputasi perusahaan, dan persepsi klaim nasabah.

\section{DAFTAR PUSTAKA}

Adisaputro, A. (2012). Pengaruh Premi Asuransi dan Kualitas Pelayanan Terhadap Kapuasan Nasabah Asuransi Pendidikan (Studi kasus pada AJB Bumiputera 1912 KC Eksekutif Semarang).

Akbar, Y. D. (2011). Analisis Persepsi Konsumen Terhadap Dimensi Ekuitas Merel pada PT. Asuransi Sinarmas Solo.

Chaudhary, S., Kaur, J., \& Khalsa, L. (2016). Consumer Perception Regarding Life Insurance Policies .

Darwin , S., \& Kunto, Y. S. (2014, Januari). Analisis Pengaruh Kualitas Layanan Terhadap LOyalitas Pelanggan dengan Kepuasan dan Kepercayaan Pelanggan Sebagai Variabel Intervening pada Asuransi Jiwa Manulife Indonesia-Surabaya. Jurnal Manajemen Pemasaran Petra, II(1).

Hassan, R. (2016). Customer Perceptiom of Green Advertising in The Context of Eco-Frindly FMCGs.

Imran Khan, M. Z. (2014). Building Company Reputation And Brand Equity Throgh CSR The Mediating Role of Trust.

Inayaturrochmah, \& Kartikasari. (2018). Analisis Kualitas Layanan Asuransi Dalam Proses Ganti Rugi Kendaraan (Klaim) Nasabah PT. Asuransi Central Asia Cabang Batam.

Kurnain, D. (2017). Analisis Klaim pada Produk Asuransi Pendidikan (Studi Kasus pada PT. Asuransi Jiwa BRIngin Life).

Muttaqin, I. (2013). Analisis Pengaruh Kualitas Pelayanan Terhadap Kepuasan Nasabah pada Asuransi Jasaraharja Putera Semarang.

Purnomo, E., \& Widowati, R. (2019, Februari). Pengaruh Persepsi Nasabah BRI Pada Kualitas Layanan Terhadap Kepuasan Dan Loyalitas Nasabah BRI Kanca Wonosari. Jurnal Bisnis Teori dan Implementasi, $X, 52-64$.

Purwa, I. N., \& Ardani, I. K. (2018). Peran Kepercayaan Nasabah Dalam Memediasi Pengaruh Kualitas Pelayanan Terhadap Kepuasan Nasabah. E-Junal Manajemen Unud, 7(1), 192-220.

Shalekhah, N. R. (2015). Analisis Pengaruh Reputasi Perusahaan Dan Kompetensi Tenaga Marketeng Terhadap Keputusan Nasabah Menggunakan Jasa Asuransi AJB Bumiputera Syari'ah Semarang.

Sugiyono. (2011). Metode Penelitian Kuantitatif, Kualitatif dan R\&D. Bandung. 
Sugiyono. (2013). Metode Penelitian Kuantitatif, Kualitatif, dan $R \& D$. Bandung.

Taroreh, O., Jorie, R. J., \& Wenas, R. (2015, September). Pengaruh Persepsi Nasabah Dan Kepercayaan Terhadap Penggunaan Jasa Asuransi Pada Asuransi Jasindo Manado. Jurnal EMBA, III(3), 312-321.

Tjipyono, F. (2015). Startegi Pemasaran (Edisi 4 ed.). Yogyakarta.

Tung, L. (2019). The Effects of Leadership Style Quality. Departement of Marketeng and Distribution Management.

Utari, D. S. (2015, Oktober). Pengaruh Reputasi Perusahaan Terhadap Loyalitas Nasabah Jasa Asuransi pada PT. Asuransi BSAM Cabang Pekanbaru. Jom FISIP, II(2).

Wijaya, M. (2019). Pengaruh Kualitas Pelayanan Terhadap Kepuasan Nasabah pada PT. Asuransi Ramayana.

Wikhann, W. (2019). Innovation, Sustainable HRM and Customer Satisfaction . 